Technical Note

\title{
Comparison between Different Rotary Mowing Systems: Testing a New Method to Calculate Turfgrass Mowing Quality
}

\author{
Michel Pirchio *, Marco Fontanelli, Fabio Labanca, Christian Frasconi, Luisa Martelloni (D,

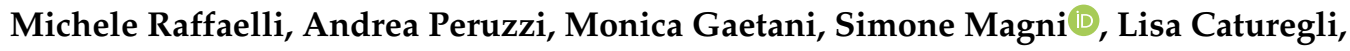 \\ Marco Volterrani and Nicola Grossi $\mathbb{D}$ \\ Department of Agriculture, Food and Environment, University of Pisa, 56124 Pisa, Italy; \\ marco.fontanelli@unipi.it (M.F.); fabiolabanca@yahoo.it (F.L.); christian.frasconi@unipi.it (C.F.); \\ lmartelloni@agr.unipi.it (L.M.); michele.raffaelli@unipi.it (M.R.); andrea.peruzzi@unipi.it (A.P.); \\ monica.gaetani@unipi.it (M.G.); simone.magni@unipi.it (S.M.); lisa.caturegli@gmail.com (L.C.); \\ marco.volterrani@unipi.it (M.V.); nicola.grossi@unipi.it (N.G.) \\ * Correspondence: michel.pirchio@for.unipi.it
}

Received: 7 September 2018; Accepted: 29 September 2018; Published: 2 October 2018

\begin{abstract}
Poor quality in turfgrass mowing is highlighted by the shredded leaf tips with necrotic tissues that give an unsightly brownish colour to the turf and may also lead to turf disease. Mowing quality is also typically assessed by visual rating, thus the score depends on the person doing the assessment. To make the evaluation of mowing quality not subjective, an innovative method was developed. The aim of the trial was to examine the effects of different mowing systems and two different nitrogen rates (100 and $200 \mathrm{~kg} \mathrm{ha}^{-1}$ ) on two turfgrass species in order to test the new mowing quality calculation. Three different mowing systems were used: a battery-powered rotary mower set at $3000 \mathrm{rpm}$ and $5000 \mathrm{rpm}$ respectively and a gasoline-powered rotary mower set at full throttle. The battery-powered mower at low blade rpm produced a poorer mowing quality and turf quality than the gasoline-powered mower and battery-powered mower at high rpm, which produced a similar mowing quality and turf quality. Leaf tip damage level values showed a significant correlation with the results of the visual mowing quality assessment. Lower leaf tip damage level values (slightly above 1) corresponded to higher visual mowing quality scores (around 8).
\end{abstract}

Keywords: rotary mowing; dull blades; leaf shredding

\section{Introduction}

Mowing plays a key role in turfgrass management [1,2] and is one of the most frequent and intensive stresses for a turfgrass since it removes part of the photosynthetic leaf area [2]. The specific features of each turfgrass species should be considered when mowing the turf [1].

To produce the same amount of dry matter, warm-season species require less water, thus are more suitable for Mediterranean climates [3-5]. Warm-season species also have superior recovery and wear resistance compared to cool-season species [6,7]. Some warm-season species are hard-to-mow such as zoysiagrass (Zoysia spp.) and bermudagrass (Cynodon spp.) [3]. Mowers working on hard-to-mow sports turf species need to have their blades sharpened more frequently [8]. Hard-to-mow turf species have a high content of plant fibre hemi-cellulose that improves wear resistance [3,9]. Bermudagrass and its hybrid types are the most widespread warm-season species for golf course fairways and tees in the USA [10]. Bermudagrass and its hybrids are also commonly used for various sports turf applications [11]. 
For sports turfs, mowing is an important operation [12]. To have the best turf quality, the blades need to be sharpened so as to perform a clean cut with no shredding $[2,13]$. The quality of the mowing is reflected in the evenness of cut of the turfgrass leaves [3]. The mowing quality should always be as high as possible, especially for high quality sports turfs [1,2]. Dull mower blades can lead to shredded leaf tips $[1,2,13]$. After a few hours, the shredded leaf tips dry out, giving the turf a brownish and unsightly appearance [2,13]. Dull mower blades are also believed to increase the risk of turf disease [14]. However, Ellram et al. [15] found that Sclerotinia homoeocarpa (Dollar Spot) fungal disease incidence was not affected by mower blade sharpness.

Leaf shredding can also change how much water the turfgrass consumes. It is commonly believed that leaf shredding due to dull mower blades will increase water consumption, however Steinegger et al. [16] found that mowing a turf with dull blades reduced water consumption because a shredded turfgrass has a slower recovery and a lower shoot density. The fewer and slower growing plants will absorb less water.

Turfgrass mowers are generally divided into three groups: rotary mowers, reel mowers and flail mowers. Trenholm et al. [1] claim that flail mowers do not equal the mowing quality of rotary or reel mowers, thus their use should be limited to low-maintenance sites that are cut infrequently. Conversely, Parish and Fry [17] found that a properly sharpened flail mower can yield the same turf quality and mowing quality as a rotary mower.

Rotary mowers are the most widespread and versatile machines for home lawn maintenance in Italy [18]. Gasoline rotary mowers are usually chosen for larger home lawns, while electric rotary mowers are usually chosen for smaller home lawns. Electric rotary mowers are supplied with electricity using a cord or a battery. In the past, electric rotary mowers working on private lawns in Italy were supplied only with a cord. In fact, battery powered rotary mowers are still not in widespread use since their cost is higher compared to cord-supplied models and the surface they can cover usually ranges from 500 to $1000 \mathrm{~m}^{2}$ [18].

Both gasoline-powered and electric-powered rotary mowers share the same cutting principles and can both be equipped for mulching. Originally, the rpm adjustment of gasoline-powered rotary mowers could not be set precisely. The trend was thus to use gasoline-powered rotary mowers at full throttle. Technologically advanced machines such as battery-powered rotary mowers offer the possibility of precisely setting the revolutions per minute (rpm) value of the cutting blades. Unfortunately, it is still unknown whether battery-powered and gasoline-powered rotary mowers yield a different mowing quality.

Mowing quality is mainly evaluated by a visual assessment [19] and depends on the skills of the person observing the tips of the leaves after mowing, thus data collected by different people may vary. Howieson and Christians [2] studied the effects of four different mower settings (using a reel mower) and of trinexapac-ethyl on the turf quality and mowing quality of creeping bentgrass (Agrostis stolonifera L.). The mowing quality was assessed using three different methods: visual assessment, leaf tissue chlorophyll content and ethylene production, measuring the perimeter of the necrotic area $24 \mathrm{~h}$ after mowing. The four settings of the reel mower were related to the reel/bedknife contact. The four reel mower settings were: (A) slight contact, sharp blade; (B) no contact, sharp blade; (C) slight contact, dull blade; (D) no contact, dull blade. Mower setting (A) produced the lowest mowing injury and the highest turf quality and chlorophyll content. Mower setting (D) produced the lowest turf quality, chlorophyll content and the highest mowing injury, with the highest number of ragged leaf tips and necrotic tissues. Mower settings (B) and (C) produced an intermediate turf quality, chlorophyll content and mowing injury, however in some cases mower setting (C) produced similar results to mower setting (A). Howieson and Christians [20] also tested the blade sharpness and mowing injury of a reel mower which had been sharpened in different ways. To assess mowing injury, the authors [20] did not use a visual assessment but measured the length of the necrotic area due to leaf tip shredding. Carbide milling led to the lowest mowing injury and the greatest chlorophyll content, while cylindrical grinding led to the highest mowing injury and lowest chlorophyll content. 
However, a trial to evaluate mower sharpness has not been carried out using rotary mowers. The aim of this study was to compare the effects of three different turfgrass mowing systems and two different nitrogen rates in order to test a new method developed at the University of Pisa to assess objective turfgrass mowing quality.

\section{Materials and Methods}

The experimental trial was carried out in S. Piero a Grado, Pisa $\left(43^{\circ} 39^{\prime} \mathrm{N} 10^{\circ} 21^{\prime} \mathrm{E}, 5 \mathrm{~m}\right.$ a.s.l.) in 2017 from May to November on a 14-month-old bermudagrass hybrid (Cynodon dactylon [L.] Pers. $\mathrm{x}$ Cynodon. transvaalensis Burtt-Davy) cv Patriot stand and on a two-year-old tall fescue (Festuca arundinacea Schreb.) cv Grande stand. The stands were established on a soil with the following properties: $91 \%$ sand, $5 \%$ silt, $4 \%$ clay, $\mathrm{pH} 6.5,1.3 \mathrm{~g} \mathrm{~kg}^{-1}$ of organic matter; EC $0.46 \mathrm{dS} \mathrm{m}^{-1}$, water availability $3.45 \% w / w$.

On 22 May, a two-way randomized blocks experimental design $(\mathrm{A} \times \mathrm{B})$ with three replications was carried out. Factor (A) consisted in two nitrogen rates (100 and $200 \mathrm{~kg} \mathrm{ha}^{-1}$ ) applied on 22 May and on 30 August with a rotary spreader using ammonium sulphate (21-0-0). Factor (B) consisted in three different walk-behind mowing systems: (1) gasoline rotary mower with a blade revolving speed of $2800 \mathrm{rpm}(\mathrm{GM})$; (2) battery powered electric mower revving at $3000 \mathrm{rpm}$ (BMS); (3) battery powered electric mower revving at $5000 \mathrm{rpm}(\mathrm{BMF})$. The experimental area of each turf species was $216 \mathrm{~m}^{2}$, subdivided into three blocks, each of $72 \mathrm{~m}^{2}(6 \times 12 \mathrm{~m})$. The single plot was $12 \mathrm{~m}^{2}(3 \times 4 \mathrm{~m})$. Working speed was $3 \mathrm{~km} \mathrm{~h}^{-1}$. All mowers were equipped for clipping removal. The blades of all mowers were sharpened before every assessment with an angle grinder.

The gasoline-powered mower used in this trial was a Honda mod. HRD 536 HX (Honda France Manufacturing, Ormes, France). The mower was a self-propelled walk-behind rotary mower that can be equipped with mulching blades. The drive is hydrostatic, allowing a speed variation from 0 to $4.7 \mathrm{~km} \mathrm{~h}^{-1}$. The working width was $53 \mathrm{~cm}$. Cutting height was adjustable from 1.4 to $7.6 \mathrm{~cm}$. The power generator was a four-stroke gasoline engine with an output of $2.7 \mathrm{~kW}$, with an overhead camshaft and a displacement of $160 \mathrm{~cm}^{3}$.

The battery-powered mower used was a Pellenc mod. Rasion Smart (Pellenc, Pertuis, France), which was a battery-powered self-propelled walk-behind rotary mower. This machine had two counter-revolving cutting blades, for a total working width of $60 \mathrm{~cm}$. The machine was powered by three brushless electric motors, one for the cutting blades and two for the rear driving wheels. Each rear driving wheel was powered by a single electric motor, allowing each driving wheel to move independently from the others. The cutting height could be adjusted from 2.5 to $7.5 \mathrm{~cm}$ in increments of $1.0 \mathrm{~cm}$ with an electronic device. The speed of the electric drive could be electronically adjusted from 1 to $5 \mathrm{~km} \mathrm{~h}^{-1}$ in increments of $1 \mathrm{~km} \mathrm{~h}^{-1}$. The revolving speed of the cutting blades could also be electronically adjusted, ranging from 3000 to $5000 \mathrm{rpm}$. The battery capacity was $1100 \mathrm{Ah}$.

Plots were mowed once per week. Mowing height was $3.5 \mathrm{~cm}$. Irrigation was applied as necessary to avoid wilt.

Every three weeks, starting on 17 May for the tall fescue stand and on 7 June for the bermudagrass stand, the following parameters were assessed and determined:

- $\quad$ turf quality with visual rating: $(1=$ poor; $9=$ excellent), 6 considered acceptable [19];

- $\quad$ subjective mowing quality assessed with visual rating: $(1=$ uneven cut edge of leaf; $9=$ perfect cut edge of leaf);

- $\quad$ leaf tip damage level $(1$ = excellent cut, no shredding at all; a greater value of leaf tip damage level indicates more leaf shredding).

To determine the level of leaf tip damage, 12 fully expanded leaves per plot were collected $24 \mathrm{~h}$ after being cut with freshly sharpened blades (first mowing since sharpening). Leaves were attached to an A4 sheet. Digital imagery was acquired using a scanner (Epson mod. Stylus Photo RX585) at 4800 dpi resolution. Using Sketchup ${ }^{\circledR}$ software, the pictures of the leaves were enlarged 50 times for 
measuring (Figures 1 and 2). The leaf tip damage level was calculated as the ratio between the length $(\mathrm{mm})$ of the actual cut "LE" (with possible shredded tips) and length of the ideal cut " $\mathrm{LI}^{\prime}$ (with no shredding at all) tangential to the edge of the leaf after the cut:

$$
\text { Leaf tip damage level }=\mathrm{LE} / \mathrm{LI}[\mathrm{mm} / \mathrm{mm}]
$$

When the leaf tip damage level is 1, the mowing quality is excellent (no shredding at all, perfect cut). As leaf tip damage level values increase mowing quality decreases.

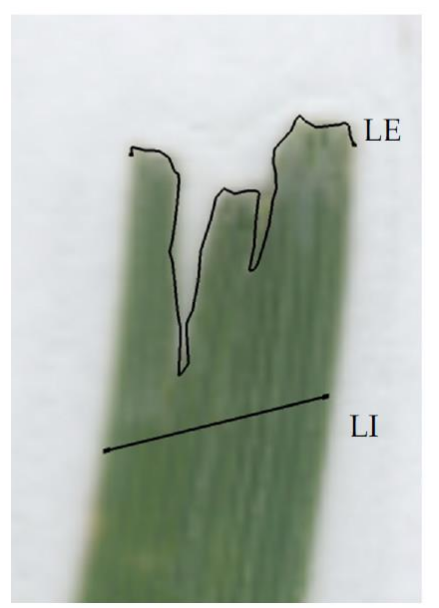

Figure 1. Leaf tip damage level $=3.50$.

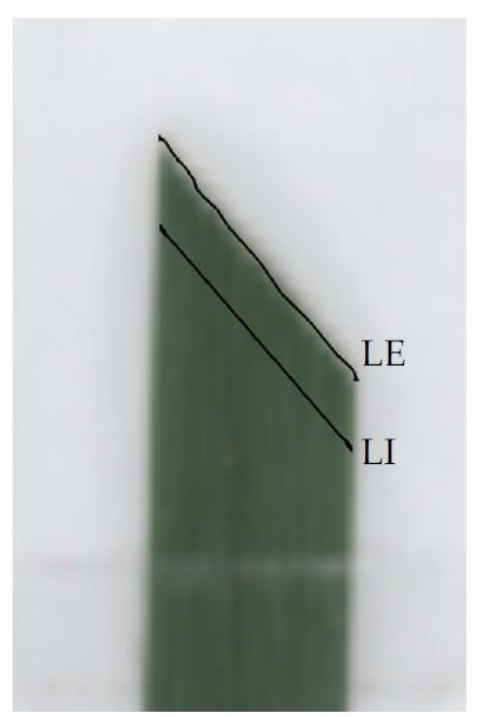

Figure 2. Leaf tip damage level $=1.07$.

Statistical analysis of biometric data was carried out with COSTAT 6.400 (CoHort Software, Monterey, CA, USA). All data were analysed by two-way analysis of variance (ANOVA) and an all pairwise Fisher's least significant difference test (LSD) at the probability level of 0.05 .

Leaf tip damage level data and subjective mowing quality data were analysed with a linear correlation and the Pearson correlation coefficient was determined.

\section{Results}

There was no significant interaction between the nitrogen rates and mowing system. The single effects of nitrogen rates and mowing system were statistically significant $(p<0.05)$ for both bermudagrass and tall fescue (Table 1). 
Table 1. Results of analysis of variance testing the effects of nitrogen rates, mowing system and their interaction on turf quality, subjective mowing quality and leaf tip damage level. The two species were analysed separately.

\begin{tabular}{|c|c|c|c|}
\hline Parameter & Nitrogen Rates (A) & Mowing System (B) & $(\mathrm{A}) \times(\mathrm{B})$ \\
\hline \multicolumn{4}{|l|}{ (a) Bermudagrass hybrid } \\
\hline Turf quality (7 June) & * & * & ns \\
\hline (27 June) & * & * & ns \\
\hline (18 July) & * & * & ns \\
\hline (30 August) & * & * & ns \\
\hline (20 September) & * & * & ns \\
\hline (12 October) & * & * & ns \\
\hline Subjective mowing quality (7 June) & * & * & ns \\
\hline (27 June) & * & * & ns \\
\hline (18 July) & $*$ & * & ns \\
\hline (30 August) & * & * & ns \\
\hline (20 September) & * & * & ns \\
\hline (12 October) & * & * & ns \\
\hline Leaf tip damage level (7 June) & * & * & ns \\
\hline (27 June) & * & * & ns \\
\hline (18 July) & * & * & ns \\
\hline (30 August) & * & * & ns \\
\hline (20 September) & * & * & ns \\
\hline (12 October) & * & * & ns \\
\hline \multicolumn{4}{|l|}{ (b) Tall fescue } \\
\hline Turf quality (17 May) & $*$ & * & ns \\
\hline (7 June) & * & * & ns \\
\hline (27 June) & * & * & ns \\
\hline (18 July) & * & * & ns \\
\hline (30 August) & * & * & ns \\
\hline (20 September) & * & * & ns \\
\hline (12 October) & * & * & ns \\
\hline (2 November) & * & * & ns \\
\hline Subjective mowing quality (17 May) & * & * & ns \\
\hline (7 June) & * & * & ns \\
\hline (27 June) & * & * & ns \\
\hline (18 July) & * & * & ns \\
\hline (30 August) & * & * & ns \\
\hline (20 September) & * & * & ns \\
\hline (12 October) & * & * & ns \\
\hline (2 November) & * & * & ns \\
\hline Leaf tip damage level (17 May) & * & * & ns \\
\hline (7 June) & $*$ & * & ns \\
\hline (27 June) & * & * & ns \\
\hline (18 July) & * & * & $\mathrm{ns}$ \\
\hline (30 August) & * & * & ns \\
\hline (20 September) & * & * & $\mathrm{ns}$ \\
\hline (12 October) & * & * & ns \\
\hline (2 November) & * & * & ns \\
\hline
\end{tabular}

${ }^{*}=p<0.05 ; \mathrm{ns}=$ not significant.

As expected, higher nitrogen rates increased turf quality for both turf species (data are not shown). Nitrogen rates had an effect on both bermudagrass and tall fescue leaf tip damage levels (Figures 3 and 4). Regardless of species, leaf tip damage level was higher when $100 \mathrm{~kg} \mathrm{ha}^{-1}$ nitrogen rate was applied. 


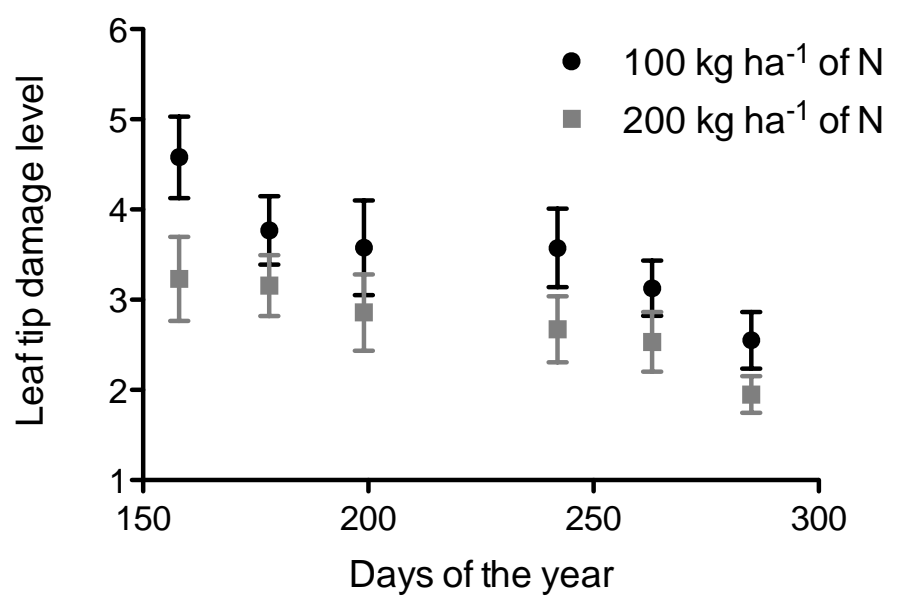

Figure 3. Effects of nitrogen rates on bermudagrass leaf tip damage level (Equation (1)) on 7 June, 27 June, 18 July, 30 August, 20 September and 12 October. For each assessment date, leaf tip damage level values were statistically different at $p<0.05$ when nitrogen rate 100 and $200 \mathrm{~kg} \mathrm{ha}^{-1}$ were applied.

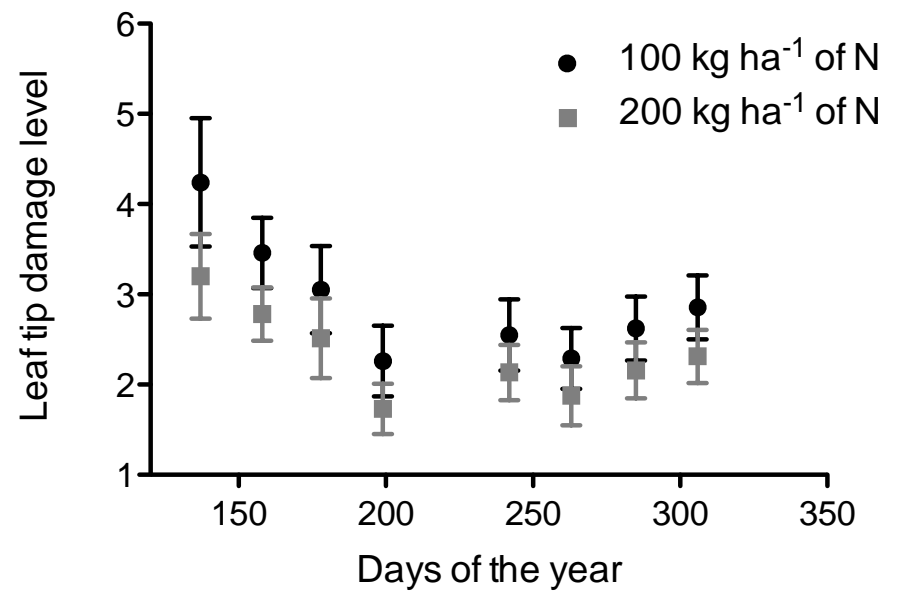

Figure 4. Effects of nitrogen rates on tall fescue leaf tip damage level (Equation (1)) on 17 May, 7 June, 27 June, 18 July, 30 August, 20 September, 12 October and 2 November. For each assessment date, leaf tip damage level values were statistically different at $p<0.05$ when nitrogen rate 100 and $200 \mathrm{~kg} \mathrm{ha}^{-1}$ were applied.

When the turf was mown with the battery-powered mower revving at $3000 \mathrm{rpm}$, the turf quality of both turf species was often lower with respect to the turf mown by the gasoline-powered mower and the battery-powered mower revving at $5000 \mathrm{rpm}$ (Table 2). Gasoline-powered mower and the battery-powered mower revving at $5000 \mathrm{rpm}$ often produced similar turf quality values.

Table 2. Mowing system mean effect on bermudagrass and tall fescue turf quality $(1=$ poor, 9 = excellent), where BMS = battery-powered mower revving at $3000 \mathrm{rpm}, \mathrm{BMF}=$ battery-powered mower revving at $5000 \mathrm{rpm}$ and $\mathrm{GM}=$ gasoline-powered mower.

\begin{tabular}{ccccccccc}
\hline & \multicolumn{9}{c}{ Turf Species } \\
\cline { 2 - 9 } & \multicolumn{9}{c}{ Bermudagrass } & \multicolumn{3}{c}{ Tall Fescue } \\
\hline Mowing system & 17 May & 27 June & 30 August & 2 November & 7 June & 18 July & 30 August & 12 October \\
\hline BMS & 6.2 & 6.3 & 6.3 & 6.6 & 7.3 & 7.1 & 6.8 & 6.4 \\
BMF & 6.9 & 6.8 & 6.8 & 7.7 & 8.0 & 7.8 & 7.6 & 7.0 \\
GM & 6.9 & 6.7 & 6.9 & 7.4 & 7.9 & 7.8 & 7.7 & 7.2 \\
LSD & 0.5 & 0.5 & 0.5 & 0.5 & 0.5 & 0.5 & 0.5 & 0.5 \\
\hline
\end{tabular}

${ }^{*} \mathrm{LSD}=$ least significant difference at $p<0.05$. 
The mowing system also had an effect on the bermudagrass and tall fescue subjective mowing quality (Table 3), in particular the battery-powered mower revving at $3000 \mathrm{rpm}$ often produced a lower subjective mowing quality values on both bermudagrass and tall fescue. Conversely, the gasoline-powered mower and battery-powered mower revving at $5000 \mathrm{rpm}$ produced a higher mowing quality on either of the turf species.

Table 3. Mowing system mean effect on bermudagrass and tall fescue subjective mowing quality $(1=$ poor, 9 = excellent $)$, where BMS = battery-powered mower revving at $3000 \mathrm{rpm}, \mathrm{BMF}=$ battery-powered mower revving at $5000 \mathrm{rpm}$ and $\mathrm{GM}=$ gasoline-powered mower.

\begin{tabular}{ccccccccc}
\hline & \multicolumn{9}{c}{ Turf Species } \\
\cline { 2 - 9 } & \multicolumn{9}{c}{ Bermudagrass } & \multicolumn{3}{c}{ Tall Fescue } \\
\hline Mowing system & 17 May & 27 June & 30 August & 2 November & 7 June & 18 July & 30 August & 12 October \\
\hline BMS & 6.5 & 6.5 & 6.7 & 6.5 & 6.6 & 6.5 & 6.6 & 7.3 \\
BMF & 7.4 & 7.3 & 7.3 & 7.4 & 7.1 & 7.3 & 7.3 & 7.4 \\
GM & 7.3 & 7.4 & 7.5 & 7.4 & 7.0 & 7.3 & 0.5 & 0.5 \\
LSD * & 0.5 & 0.5 & 0.5 & 0.5 & 0.5 & 0.5 & 0.5 \\
\hline
\end{tabular}

The mowing system also had an effect on the bermudagrass leaf tip damage level (Figure 5) and tall fescue leaf tip damage level (Figure 6). The leaf tip damage level of both turf species was higher when the turf was mown with the battery-powered mower revving at $3000 \mathrm{rpm}$.

The gasoline-powered mower and battery-powered mower revving at $5000 \mathrm{rpm}$ produced similar leaf tip damage on both turf species.

Bermudagrass and tall fescue leaf tip damage level values resulted in a significant correlation $(\mathrm{r}=-0.86$ and -0.79 , respectively) with subjective mowing quality values (Figures 7 and 8 , respectively). Lower leaf tip damage level values led to a greater subjective mowing quality for both turf species.

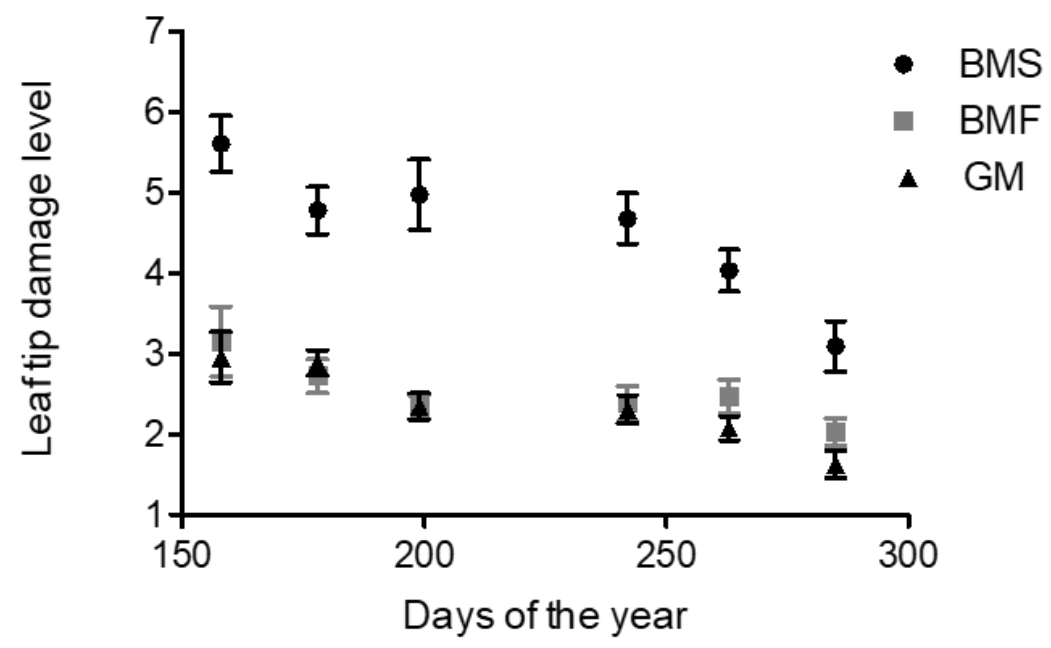

Figure 5. Mowing system effect on bermudagrass leaf tip damage level (Equation (1)) on 7 June, 27 June, 18 July, 30 August, 20 September and 12 October. BMS = battery-powered mower revving at $3000 \mathrm{rpm}, \mathrm{BMF}=$ battery-powered mower revving at $5000 \mathrm{rpm}$ and $\mathrm{GM}=$ gasoline-powered mower. Letters " $a$ " and " $b$ " indicate statistically different values at $p<0.05$ for each assessment date. 


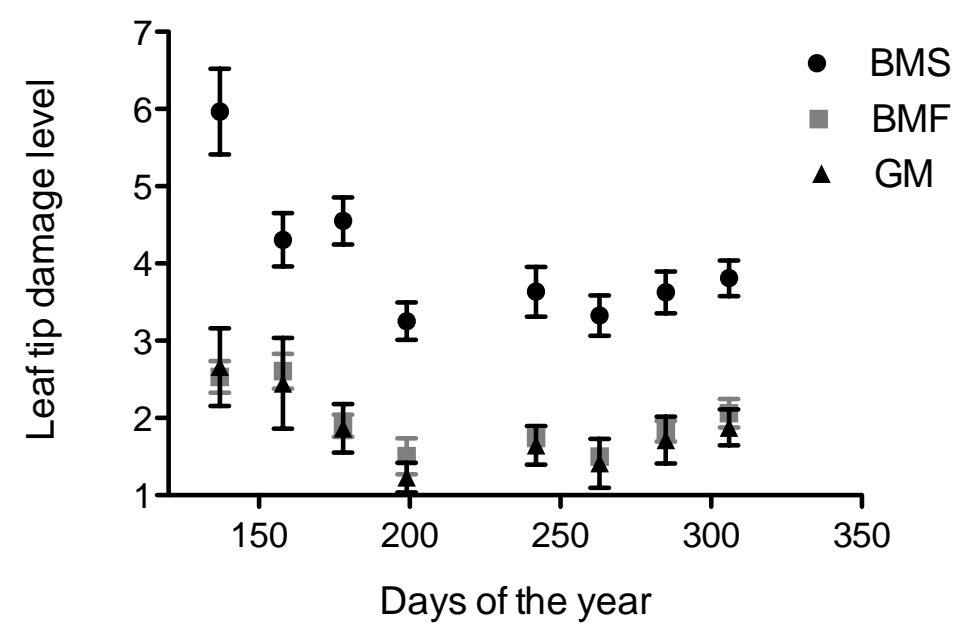

Figure 6. Mowing system effect on tall fescue leaf tip damage level (Equation (1)) on 17 May, 7 June, 27 June, 18 July, 30 August, 20 September, 12 October and 2 November. BMS = battery-powered mower revving at $3000 \mathrm{rpm}, \mathrm{BMF}=$ battery-powered mower revving at $5000 \mathrm{rpm}$ and $\mathrm{GM}=$ gasoline-powered mower. Letters "a" and " $\mathrm{b}$ " indicate statistically different values at $p<0.05$ for each assessment date.

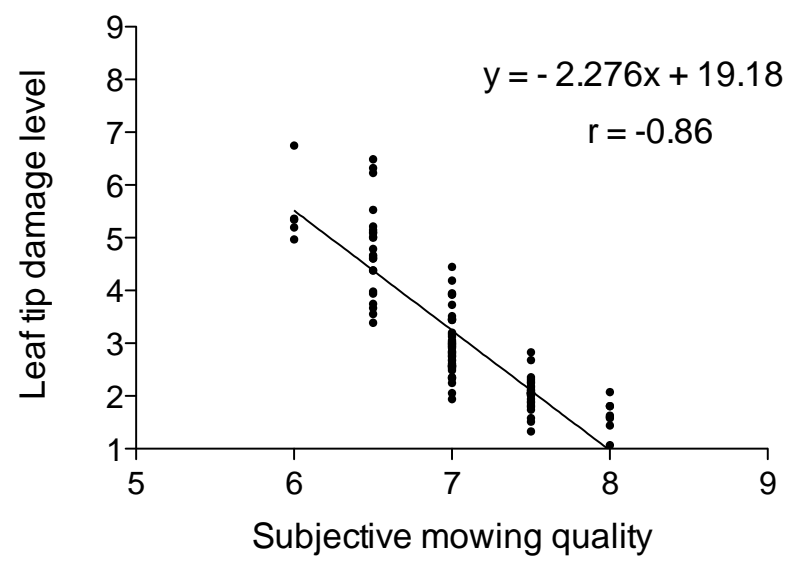

Figure 7. Bermudagrass leaf tip damage level (Equation (1)) and subjective mowing quality (1 = poor, $9=$ excellent) correlation and Pearson's correlation coefficient (r). All replicates are reported.

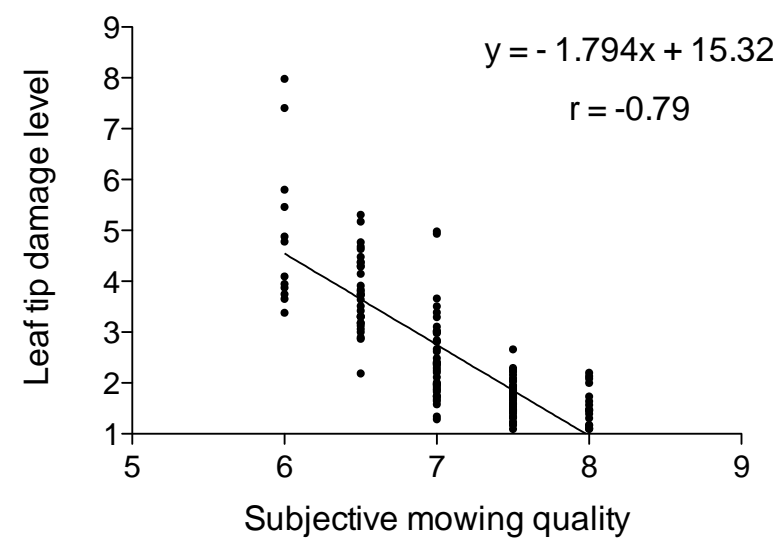

Figure 8. Tall fescue leaf tip damage level (Equation (1)) and subjective mowing quality $(1=$ poor, $9=$ excellent) correlation and Pearson's correlation coefficient (r). All replicates are reported.

\section{Discussion}

As expected, nitrogen fertilization increased the turf quality and mowing quality of both bermudagrass and tall fescue throughout the whole trial. As observed by Gibeault and Hanson [21] 
on perennial ryegrass, nitrogen fertilization helps keep leaf tissues more turgid and less stringy, thus reducing leaf shredding during mowing. Regarding the mowing quality of rotary mowers, a higher revolving speed of the cutting blade usually results in a better mowing quality since this increases the impact on the grass leaves. However, in the present research, the differences in leaf tip damage level showed that the battery-powered mower revving at $3000 \mathrm{rpm}$ produced more leaf shredding than the gasoline-powered mower revving at $2800 \mathrm{rpm}$ on both bermudagrass and tall fescue. In addition, on bermudagrass and tall fescue, the battery-powered mower revving at $5000 \mathrm{rpm}$ and the gasoline-powered mower revving at $2800 \mathrm{rpm}$ showed the same leaf tip damage levels. This is probably because the battery-powered mower had two $30 \mathrm{~cm}$ blades, while the gasoline-powered mower had a single $53 \mathrm{~cm}$ blade. The same angular mower blade speed corresponds to different peripheral speeds. A higher peripheral speed produces a stronger impact on the grass leaves leading to a higher mowing quality.

Although mowing dates were not considered as a factor, being irrigation only applied to avoid wilt, we observed the trend of bermudagrass and tall fescue leaf tip damage level during the period of the trial. Interestingly, the bermudagrass leaf tip damage levels tended to decrease from the beginning of the trial until the end (from summer to autumn), the tall fescue leaf tip damage levels first decreased (from spring to summer) and then increased until the end of the trial (from summer to autumn), following the turfgrass growth rate shown by Turgeon [3]. Figures 7 and 8 also show a correlation between the leaf tip damage levels and subjective mowing quality values. A high leaf tip damage level corresponds to a lower subjective mowing quality. However, even if there is a correlation between leaf tip damage level and visual assessment, leaf tip damage level is totally independent from the person that does the assessment and gives more realistic information of the mowing machine performances. Visual assessment may be influenced by the colour of the turf or by the intensity of light, while leaf tip damage level, being calculated from measured data, is not influenced by external factors. Moreover, leaf tip damage level can be applied to any turf species since the shape and the colour of the leaves do not affect the measurements of the leaf tip. Howieson and Christians [2] also found that a higher mowing injury corresponded to lower visual assessment mowing quality values. However, Howieson and Christians [2,20] only measured the perimeter of necrotic leaf areas without considering the width of the leaf and thus did not develop a fully objective method to assess mowing quality. In fact, two leaves with the same percentage of necrotic area (similar shredding) but with different leaf widths will give different perimeter values despite the similar shredding indicating a similar mowing quality. Howieson and Christians [2,20] found that ragged turf leaves contain less chlorophyll than optimally cut turf leaves. The chlorophyll content is important both for turf health and for optimal turf quality. More chlorophyll leads to a higher turf quality. In fact, in this trial when the mowing quality was lower, the turf colour was often not optimal, resulting in a lower overall turf quality.

\section{Conclusions}

Considering the turf quality and mowing quality values produced by the three mowing systems studied in this work, a higher peripheral mower blade speed resulted in a higher turf quality and mowing quality values, irrespectively of the type of engine employed. Setting the gasoline-powered mower at a lower power output in order to reduce power consumption also means slowing down the mower blade speed, thus decreasing the mowing quality and turf quality. Although battery-powered mower revving at $3000 \mathrm{rpm}$ produced an acceptable turf quality, in order to have the best turf quality it is preferable to use the battery-powered mower revving at $5000 \mathrm{rpm}$ or the gasoline-powered mower at full throttle. These results have been optimally highlighted using the new method to assess objective mowing quality called leaf tip damage level. Leaf tip damage level values are not assessed but calculated from measurements of the leaf tip, thus giving an objective result. Leaf tip damage level values slightly above 1 correspond to the best visual mowing quality scores. Higher leaf tip damage level values correspond to lower visual mowing quality scores. These results demonstrated that the leaf tip damage level is a very useful and objective tool for the evaluation of mowing quality. 
The new method could also be improved by measuring the extension of the necrotic leaf area due to mower blade shredding and by carrying out a correlation with the values of the perimeter of the leaf tip after mowing. A future trial could develop specific software that automatically determines the exact mowing quality of grass leaves by just acquiring a digital image of the leaf tip.

Author Contributions: M.P., M.F., F.L., C.F., L.M., M.R., A.P., M.G., S.M., L.C., M.V., N.G. conceived and designed the experiments, performed the experiments, analysed the data, contributed analysis tools and wrote the paper.

Funding: This research received no external funding.

Acknowledgments: We would sincerely like to thank Pellenc Italia S.r.l. (Colle di Val d'Elsa, Siena, Italy) for providing the battery-powered mower, technical assistance and supporting this research.

Conflicts of Interest: The authors declare no conflict of interest.

\section{References}

1. Trenholm, L.E.; Unruh, J.B.; Cisar, J.L. Mowing Your Florida Lawn; Fact Sheet ENH 10; Environmental Horticulture Department, Florida Cooperative Extension Service, Institute of Food and Agricultural Sciences, University of Florida: Gainesville, FL, USA, 2009.

2. Howieson, M.J.; Christians, N.E. Mower Settings, PGRs Affect Turfgrass Quality; Golf Course Management: Lawrence, KS, USA, June 2001; pp. 65-70.

3. Turgeon, A.J. Turfgrass Management, 9th ed.; Prentice Hall: Upper Saddle River, NJ, USA, 2012.

4. Croce, P.; De Luca, A.; Mocioni, M.; Volterrani, M.; Beard, J.B. Adaptibility of warm season turfgrass species and cultivars in a mediterranean climate. Acta Hortic. 2004, 661, 365-368. [CrossRef]

5. Volterrani, M.; De Bertoldi, C. I Generi di Macroterme per i Tappeti Erbosi nel Bacino del Mediterraneo: Cynodon, Paspalum e Zoysia, 8th ed.; Polistampa: Florence, Italy, 2012.

6. Volterrani, M.; Grossi, N.; Pardini, G.; Miele, S.; Gaetani, M.; Magni, S. Warm season turfgrass adaptation in Italy. Int. Turfgrass Soc. Res. J. 1997, 8, 1344-1354.

7. Lulli, F.; Volterrani, M.; Grossi, N.; Armeni, R.; Stefanini, S.; Guglielminetti, L. Physiological and morphological factors influencing wear resistance and recovery in C3 and C4 turfgrass species. Funct. Plant Biol. 2012, 39, 214-221. [CrossRef]

8. Bevard, D.; Foy, J.; Lowe, T.; White, B. Alternative grasses: Panacea or problem? USGA Green Sect. Rec. 2005, 43, 26-28.

9. Shearman, R.C.; Beard, J.B. Turfgrass wear tolerance mechanisms: II. Effects of cell wall constituents on turfgrass wear tolerance. Agron. J. 1975, 67, 211-215. [CrossRef]

10. Trappe, J.M.; Karcher, D.E.; Richardson, M.D.; Patton, A.J. Bermudagrass and zoysiagrass cultivar selection: Part 1, clipping yield, scalping tendency, and golf ball lie. Appl. Turfgrass Sci. 2011, 8. [CrossRef]

11. Aldous, D.E.; Chivers, I.H. Sports Turf and Amenity Grasses: A Manual for Use and Identification; Landlinks Press: Collingwood, VIC, Australia, 2002.

12. Beard, J.B. Turfgrass: Science and Culture; Prentice Hall: Englewood Cliffs, NJ, USA, 1973.

13. Smith, T.M.; Patchan, G.; Payne, K.T.; Kaufman, J.E. Mowing A Lawn. In Turf Tips for the Homeowner; US. Extension Bulletin E-1487, File 29.22; Michigan State University Extension Service: East Lansing, MI, USA, 1981.

14. Emmons, R. Turfgrass Science and Management; Delmar: Albany, NY, USA, 1995.

15. Ellram, A.; Horgan, B.; Hulke, B. Mowing strategies and dew removal to minimize dollar spot on creeping bentgrass. Crop Sci. 2007, 47, 2129-2137. [CrossRef]

16. Steinegger, D.H.; Shearman, R.C.; Riordan, T.P.; Kinbacher, E.J. Mower Blade Sharpness Effects on Turf. Agron. J. 1983, 75, 479-480. [CrossRef]

17. Parish, R.L.; Fry, J.D. Mower effects on turfgrass quality. Appl. Eng. Agric. 1997, 13, 715-717. [CrossRef]

18. Grossi, N.; Fontanelli, M.; Garramone, E.; Peruzzi, A.; Raffaelli, M.; Pirchio, M.; Martelloni, L.; Frasconi, C.; Caturegli, L.; Gaetani, M.; et al. Autonomous Mower Saves Energy and Improves Quality of Tall Fescue Lawn. HortTechnology 2016, 26, 825-830. [CrossRef]

19. Morris, K.N.; Shearman, R.C. NTEP Turfgrass Evaluation Guidelines; National Turfgrass Evaluation Program: Beltsville, MD, USA, 2010; Available online: http:/ / www.ntep.org/cooperator.htm (accessed on 9 July 2018). 
20. Howieson, M.J.; Christians, N.E. Mower Sharpness and Creeping Bentgrass Quality of Cut. Iowa State Research Farm Progress Reports. 2006. Available online: http://lib.dr.iastate.edu/farms_reports/1026 (accessed on 9 July 2018).

21. Gibeault, V.A.; Hanson, D. Perennial ryegrass mowing quality and appearance response to three nitrogen regimes. In Proceedings of the Third International Turfgrass Research Conference; Beard, J.B., Ed.; ASA; CSSA; SSSA: Madison, WI, USA, 1980; pp. 39-43.

(c) 